Wrocławskie Studia Wschodnie

$24(2020)$

Wydawnictwo Uniwersytetu Wrocławskiego

https://doi.org/10.19195/1429-4168.24.9

\author{
SYLWIA SZAREJKO \\ ORCID: 0000-0001-8956-6227 \\ Muzeum Pamięci Sybiru
}

\title{
Deportacje Pomorzan na Sybir w świetle protokołów przesłuchań świadków Instytutu Pamięci Narodowej - casus mieszkańców Gdyni
}

\section{„Kaszubsko-pomorskie opowieści wojenne”}

Choć moment impasu w dyskursie na temat represji wobec ludności cywilnej po wkroczeniu Armii Czerwonej na ziemie polskie w 1939 roku wydaje się przełamywany, temat ten w polskiej historiografii nadal stanowi niewyeksploatowane pole badań. Świadczą o tym zarówno teksty polskich historyków ${ }^{1}$, jak i powstałe w ostatnich dekadach liczne instytucje kultury, pośród których należy przede wszystkim wymienić Instytut Pamięci Narodowej Komisję Ścigania Zbrodni przeciwko Narodowi Polskiemu², a także muzea (między innymi: Muzeum Katyńskie, Muzeum II Wojny Światowej oraz nowo powstałe Muzeum Pamięci Sybiru), mające na celu upowszechnianie wiedzy historycznej.

Represjonowanie ludności polskiej w latach 1939-1956 (a więc od momentu wkroczenia Armii Czerwonej na byłe terytorium II Rzeczypospolitej aż po

1 Zob. M. Golon, Represje Armii Czerwonej i NKWD wobec polskiej konspiracji niepodległościowej w latach 1944-1956: Część I, „Czasy Nowożytne” 1996, nr 1, s. 75-100; O sowieckich represjach wobec Polaków ze Stawomirem Kalbarczykiem, Tomaszem Łabuszewskim i Kazimierzem Krajewskim rozmawia Barbara Polak, „Biuletyn IPN”2003, nr 11 (34), s. 4-30; M. Zwolski, Represje wobec ludności cywilnej po wkroczeniu Armii Czerwonej 1944-1945 [mps tekstu udostępniony przez autora].

2 Instytut Pamięci Narodowej został powołany 19 stycznia 1999 roku na mocy ustawy z dnia 18 grudnia 1998 roku o Instytucie Pamięci Narodowej — Komisji Ścigania Zbrodni przeciwko Narodowi Polskiemu. Zob. Dz.U. z 1998 r. Nr 155, poz. 1016, http://prawo.sejm. gov.pl/isap.nsf/DocDetails.xsp?id=WDU19981551016 (dostęp: 10.12.2019). 
objęcie stanowiska I sekretarza Polskiej Zjednoczonej Partii Robotniczej przez Władysława Gomułkę) obejmowało, jak pisze Mirosław Golon, aresztowania, obozy, zabójstwa, a także inne formy prześladowań. Wzmacniało to wpływy ZSRS w Polsce, tworząc fundament pod dalszy rozwój radzieckiej polityki ${ }^{3}$. Nie powinien zatem dziwić fakt, że wiele zbrodni nie doczekało się, jak dotąd, gruntownego opracowania historycznego. Owo rzetelne opracowanie tematu wymaga, jak sądzę, oprócz dostępu do materiałów archiwalnych i szczegółowych kwerend, także odwagi w pracy badawczej, charakteryzującej się stawianiem trudnych pytań o historię. Niezbędny jest również dystans, szersza perspektywa badawcza, do której nie tylko naukowcy, ale także całe społeczeństwo ma dostęp zaledwie od 30 lat, albowiem za swoistą cezurę czasową należy tu przyjąć jakże znaczący rok 1989.

W polskiej historii istnieje wiele tak zwanych białych plam, czyli tematów niedostatecznie przepracowanych, czasami także z różnych przyczyn pomijanych, które wymagają naukowego opracowania i komentarza. Jednym z takich zagadnień wydaje się obecność Armii Czerwonej na Pomorzu po 1945 roku. Choć temat ten poruszany był w ostatnich latach, wciąż jest to zagadnienie, którego wielowątkowość tworzy niezaprzeczalny dowód na to, jak wiele jeszcze pracy przed badaczami, aby w pełni odkryć nieznane karty historii ${ }^{4}$.

Szczególną uwagę należy zwrócić na kwestię deportacji ludności z Pomorza Wschodniego (Gdańskiego) w głąb ZSRS. Zjawisko to zostało poddane analizie w pracach między innymi Mirosława Golona czy Włodzimierza Jastrzębskiego ${ }^{5}$. Jednakże, oprócz prac naukowych, historię deportacji mieszkańców Pomorza Gdańskiego, w tym wielu Kaszubów, poznajemy także dzięki wydawnictwom wspomnieniowym, które przybliżają czytelnikom losy „świadków historii”. Osobiste wyznania i indywidualne historie poszczególnych osób układają się jednak, co oczywiście nie powinno dziwić, we wspólnotowe doświadczenie czasu okupacji mieszkańców Pomorza Gdańskiego, w tym regionu Kaszub ${ }^{6}$. Obszar ten, dotknięty skądinąd podwójną okupacją

3 M. Golon, Represje Armii Czerwonej..., s. 77.

4 Zob. G. Baziur, Armia Czerwona na Pomorzu Gdańskim 1945-1947, Warszawa 2003; B. Chrzanowski, A. Gąsiorowski, K. Steyer, Polska podziemna na Pomorzu w latach 19391945, Warszawa 2005; T. Gliniecki, D. Panto, Krzywy obraz wojny. Armia Czerwona w Gdańsku i Prusach w 1945 r., Gdańsk 2019.

5 Zob. M. Golon, „Pomorska obława”. Deportacje Polaków z Pomorza do obozów NKWD w ZSRR w 1945 roku, [w:] Polska 1939-1945: straty osobowe i ofiary represji pod dwiema okupacjami, red. W. Materski, T. Szarota, Warszawa 2009, s. 291-303; M. Golon, Deportacje Polaków z Pomorza do obozów NKWD w ZSRR w 1945 r., [w:] Przez Sybir na ziemię gdańska, cz. 2, red. C. Riedl, Gdańsk 2009, s. 9-17; oraz W. Jastrzębski W dalekim, obcym kraju: deportacje Polaków z Pomorza do ZSRR w 1945 roku, Bydgoszcz 1990.

6 Zob. E. Pryczkowski, Wspomnienia kaszubskich Sybiraków, Banino 2010; F. Troszczyłów, Los wypędzonych Pomorzan 1939-1945, Gdynia 2010.

Wrocławskie Studia Wschodnie 24, 2020

(C) for this edition by CNS 
— hitlerowską i stalinowską — zawiera pamięć historyczną deportacji w głąb ZSRS, jednakże wydaje się ona nadal niedostatecznie odkrytym polem badań historycznych. A przecież, jak pisał Golon:

Z ziem „Polski lubelskiej” [część ziem polskich wyzwolona przez Armię Czerwoną latem 1944 roku — S.Sz.] i obszarów wyzwolonych spod okupacji niemieckiej w 1945 r. NKWD wywiozło z pewnością 50 tysięcy Polaków, kwalifikując część z nich jako Niemców. Kilkanaście tysięcy spośród wywiezionych było żołnierzami AK lub uczestnikami innych struktur konspiracyjnych ${ }^{7}$.

Pośród artykułów prasowych dotyczących deportacji ludności z Pomorza w głąb ZSRS pojawia się opinia Cezarego Obrachta-Prondzyńskiego, który w rozmowie z Tomaszem Słomczyńskim, redaktorem naczelnym internetowego „Magazynu Kaszuby”, stwierdził:

O doświadczeniu wojennym Kaszubów mówiło się wśród samych Kaszubów i pomorskich badaczy na Pomorzu. Temat był obecny, ale w regionie, w grupie badaczy, intelektualistów i w obrębie lokalnych społeczności. Mówiło się o tym jedynie „między sobą”. Te kaszubsko-pomorskie opowieści wojenne nie przedostają się do ogólnopolskiej świadomości, pamięci historycznej ${ }^{8}$.

Słowa profesora znajdują potwierdzenie w publikacjach naukowych badaczy reprezentujących pomorskie ośrodki naukowe. Należy tu wskazać nazwiska między innymi Sylwii Bykowskiej ${ }^{9}$ czy Marka Adamkowicza i Iwony Joć ${ }^{10}$. Jednakże niewielkie zainteresowanie tematem represji Armii Czerwonej i NKWD wobec ludności Pomorza Gdańskiego, w tym Kaszubów, wśród szerszego grona badaczy nie wynika tylko i wyłącznie z „lokalności” tematu. Wydaje się, że owo ,wykluczenie” z ogólnopolskiego dyskursu akademickiego i opinii publicznej związane jest z tym, o czym przez wiele lat „historia milczała”, a co trafnie skonkludował w swojej wypowiedzi dla Słomczyńskiego jeden z rozmówców:

U nas raczej nie mówiło się o wojnie [...]. Bo Wehrmacht, bo zsyłki na Sybir po wojnie, razem z innymi Niemcami. Tak, dla wielu byliśmy Niemcami. I to przekonanie wcale nie minęło do końca. Czasem to słychać, nawet dzisiaj. Kogo interesuje, co my tutaj na Kaszubach mamy do powiedzenia na temat wojny? ${ }^{11}$

Kaszubi znaleźli się w tragicznej sytuacji geopolitycznej, a istniejący wewnątrz pomorskiej społeczności problem tożsamościowy sytuował tę grupę

7 M. Golon, Represje Armii Czerwonej..., s. 103.

8 T. Słomczyński, Zapomniani Sprawiedliwi wśród Narodów Świata, czyli jak Kaszubi ratowali Żydów, „Plus Minus”, https://www.rp.pl/Plus-Minus/303159914-Zapomniani-Spraw iedliwi-wsrod-Narodow-Swiata-czyli-jak-Kaszubi-ratowali-Zydow.html (dostęp: 5.12.2019).

9 Zob. S. Bykowska, Rehabilitacja i weryfikacja narodowościowa ludności polskiej w województwie gdańskim po II wojnie światowej, Gdańsk 2012.

10 Zob. Kaszubi w PRL, red. M. Adamkowicz, I. Joć, Gdańsk 2007.

11 T. Słomczyński, op. cit.

Wrocławskie Studia Wschodnie 24, 2020

(C) for this edition by CNS 
ludności, podążając za sformułowaniem Andrzeja Chodubskiego, w kategorii „obcych wśród obcych"12.

Badania dotyczące deportacji ludności Pomorza Wschodniego potwierdzają, że NKWD rozkazem nr 0016 z dnia 11 stycznia 1945 roku, przeniosło praktyki stosowane na ziemiach wschodnich II Rzeczypospolitej na obszar całego kraju $^{13}$. Początkowo na Pomorzu Wschodnim aresztowano osoby przypadkowe — mieszkańców, którzy nie mieli dokumentów albo mieli je wydane w języku niemieckim. Osoby te trafiały do specjalnych obozów w Ciechanowie, Działdowie, Poznaniu i Grudziądzu, tworzących punkty etapowe, aby następnie zostać wywiezionym w głąb ZSRS ${ }^{14}$. Deportowani z Pomorza w 1945 roku trafiali zwłaszcza do Czkałowa, Kurganu, Czelabińska, Kopiejska i Ufy. Szacuje się, że z Pomorza Gdańskiego deportowano kilkanaście tysięcy osób, w tym, jak pisze Barbara Kąkol — dyrektorka Muzeum Kaszubskiego w Kartuzach — około 4500 Kaszubów, których poszukiwania trwały jeszcze w latach pięćdziesiątych XX wieku. Znajduje to potwierdzenie w listach osób, które próbowały odnaleźć swoich krewnych i korespondowały w tej sprawie z Polskim Związkiem Zachodnim. Dokumentacja ta została przekazana do Muzeum przez dziennikarza „Głosu Kaszub” - Brunona Dompke ${ }^{15}$.

Większość wywiezionych Pomorzan powróciła do Polski w 1947 roku, inni dopiero w 1956 roku, ale jak pisze Eugeniusz Pryczkowski:

Tragizm tych ludzi zwielokrotniał fakt, że ta katorga zgotowana im przez sowieckich ,wyzwolicieli" następowała tuż po hitlerowskiej gehennie. Rosjanie szukali rzekomych win, więc szczególną nienawiść kierowali w stronę rodzin, które ujęte były na niemieckich listach narodowych (Eindeutschung), choć - jak praktyka pokazała - wcale nie było to ostatecznym powodem aresztowań. Był to jednak dla Rosjan wygodny powód, gdyż w efekcie przemocy, ludzie doświadczeni hitlerowskimi metodami, wskazywali jedni drugich bez większego uzasadnienia. To zresztą było potrzebne „wyzwolicielom”, dla których teren Kaszub był ziemią „germańców”16.

Opinia Pryczkowskiego, wydaje się także poruszać kolejną istotną kwestię w omawianym zagadnieniu. Mam tu na myśli podpisywanie Niemieckiej Listy Narodowościowej (NLN) przez ludność Pomorza Gdańskiego, co w przypadku tych terenów, w odróżnieniu od Generalnego Gubernatorstwa,

12 A. Chodubski, O mitycznym postrzeganiu tożsamości Gdyni, „Zeszyty Gdyńskie” 2016, nr 11, s. 21.

13 M.L. Krogulski, Okupacja w imię sojuszu. Armia Radziecka w Polsce 1956-1993 (fragmenty), https://forumemjot.wordpress.com/2012/05/09/okupacja-w-imie-sojuszu-armiasowiecka-w-polsce-1944-1956-fragmenty/ (dostęp: 5.12.2019). Zob. idem, Okupacja w imię sojuszu. Armia Radziecka w Polsce 1956-1993, Radzymin 2019.

14 M.L. Krogulski, Okupacja w imię sojuszu..., https://forumemjot.wordpress.com...

15 B. Kąkol, Kartuzy - 1945 r., http://www.szwajcaria-kaszubska.pl/kaszuby/muzeum-kaszubskie/item/991-kartuzy-1945-r (dostęp: 1.12.2019).

16 E. Pryczkowski, op. cit., s. 11-12.

Wrocławskie Studia Wschodnie 24, 2020

(C) for this edition by CNS 
było obligatoryjne i miało na celu zmniejszenie liczby ludności polskiej zamieszkałej na terenach wcielonych do III Rzeszy.

Miejscową ludność podzielono więc na kategorie, które według rozporządzenia w sprawie NLN wydanego 4 marca 1942 roku przez Heinricha Himmlera składały się z czterech grup. Do I grupy (Reichsdeutsche) zaliczano Niemców z pochodzenia, przyznających się do niemieckości. Do II grupy (Volksdeutsche) wpisywano Niemców z pochodzenia, nieangażujących się w niemieckie życie publiczne na terenach polskich, ale kultywujących niemiecką tradycję. Do III grupy trafiały osoby pochodzenia niemieckiego, częściowo spolonizowane lub ciążące ku niemieckości, a więc gwarantujące szybką regermanizację, na liście zaś IV grupy umieszczano osoby pochodzenia niemieckiego, które w pełni się spolonizowały ze względów społecznych i zawodowych. Co więcej, tych, którzy nie dostali obywatelstwa Rzeszy, uznano za podopiecznych państwa niemieckiego, czyli ,podludzi”, pozbawionych praw. Wpisowi podlegali obywatele polscy i obywatele Wolnego Miasta Gdańska ${ }^{17}$. Mieszkańcy Pomorza, którzy nie podpisali NLN, traktowani byli jako najgorsi wrogowie narodu niemieckiego. Stąd, jak donoszą statystyki: „do 1 I 1944 na terenie okręgu Gdańsk-Prusy Zachodnie wpisano na NLN 937 tysięcy osób (w tym do grupy I — 115 tysięcy, grupy II — 95 tysięcy, grupy III — 725 tysięcy, grupy IV -2 tysiące)"18. Należy tu także dodać, że Kaszubi byli wpisywani do III i IV grupy.

Okrucieństwo przymusu podpisania $\mathrm{NLN}^{19}$ potęguje także fakt, że gdy w 1945 roku na Pomorze wkroczyła Armia Czerwona, to w jej mniemaniu zajmowała tereny III Rzeszy, albowiem w 1939 roku Niemcy przymusowo wysiedlali z tego terenu ludność polską. W związku z tym, według sowieckiej logiki, zamieszkująca ten obszar ludność była germanofilska lub/i niemiecka. A przecież sam Adolf Hitler był przekonany, że niektóre miasta Pomorza Gdańskiego wchłonięte przez III Rzeszę i wcielone jako tak zwany okręg Gdańsk-Prusy Zachodnie (na przykład Gdynia) nie były miastami volksdeutchów ${ }^{20}$.

17 Niemiecka Lista Narodowościowa, https://www.gedanopedia.pl/gdansk/?title=NIEMIE CKA_LISTA_NARODOWO\%C5\%9ACIOWA (dostęp: 1.12.2019).

18 Ibidem.

19 Zob. Rodowici mieszkańcy Pomorza wstydza się podpisania volkslisty. ,, Terror zacząt się od pierwszych dni wojny", https://trojmiasto.wyborcza.pl/trojmiasto/1,35612,14845394,Rodowici_mieszkancy_Pomorza_wstydza_sie_podpisania.html?disableRedirects=true (dostęp: 14.12. 2019); a także W. Kulesza, Polacy wpisani na volkslistę a obowiazek stużby w Wehrmachcie w świetle wyroków Sądu Specjalnego w Toruniu, „Studia Iuridica Toruniensia” 23, 2018, s. 103-133; oraz S. Bykowska, Karać czy rehabilitować? Powojenne ustawodawstwo polskie wobec osób wpisanych na Niemiecka Listę Narodowościowa, „Czasopismo Prawno-Historyczne" 64, 2012, nr 1, s. 149-167.

20 Trzy Gdynie, „Wiadomości Polskie polityczne i literackie. Tygodnik” 1941, nr 41 (83), http://2wojna.gdynia.pl/wp-content/uploads/2017/12/14_trzy_gdynie.pdf(dostęp: 14.12.2019).

Wrocławskie Studia Wschodnie 24, 2020

(C) for this edition by CNS 
Mieszkaniec Pomorza Augustyn Kowalewski z Kartuz wojenne koleje losu opisuje następująco: „Niemiec nas gnębił, mordował, zabijał, ale to był nasz wróg, o czym wiedzieliśmy i do czego się przygotowywaliśmy. Natomiast wiele gorsze było wkroczenie Sowietów"21. Trudno nie potwierdzić słów Kowalewskiego - Stanisław Fikus (1920-2010), kaszubski twórca i działacz społeczny, w liście do redakcji „Dziennika Bałtyckiego”, który przytaczam w nieco dłuższym fragmencie, napisał:

W „Dzienniku Bałtyckim” z dnia 4.09. [2001 — E.P.] w rubryce „Pomorze” ukazała się wzmianka o tych, co z Kaszub z Pomorza zostali wywiezieni na Sybir do marca 1945 r. w zgodzie z rządem ówczesnym polskim, za zgodą Wł. Gomułki i Osóbką-Morawskim. [...] Naturalnie o tym rozmawiać, czy opowiadać surowo było zabronione, ponieważ wracający stamtąd Polacy musieli się zobowiązać i podpisać orzeczenie po przekroczeniu granicy na Bugu, potem w PUR w Poznaniu, że nigdy nie byli wywiezieni za Ural i dalej. Żadnych dokumentów nie otrzymywali, jedynie w Poznaniu w PUR zaświadczenie, że wracają do kraju. Przez cały czas nie wolno było o tym wspominać, nawet kiedy te sprawy już można było ujawnić, czyli zesłania na Syberię po 1939 r. z byłych Kresów Wschodnich czy żołnierzy AK. Te sprawy już odtajniały i można opisywać do woli, natomiast sprawa zesłania Kaszubów nie tylko w marcu, bo spotykałem ludzi, którzy wracali z robót przymusowych po zajęciu terenów przez Sowietów do samej Odry, czyli w miesiącu kwietniu, kiedy wracali z niewoli niemieckiej czy robót przymusowych, to wyłapywano polskich robotników i kierowano na Syberię. Najwięcej jednak wychwytywano w marcu 1945 kiedy zajmowano tereny Pomorza, tereny Kaszub, bo ta nacja była zawsze przetrzebiona, przed wojną również, że to nie są właściwi Polacy ${ }^{22}$.

\section{I dalej:}

Ogólnie uważano przez wiele lat, że na Pomorzu byli sami Volksdeutsche i zdrajcy. [...] nikt się tym nie interesował, nawet wyśmiewano się z niej [Sybiraczki Janiny Roraf z Lęborka — S.Sz.], że jakaś Kaszubka mówi o zsyłce na Sybir, zawsze byli to ludzie zza Buga, z Powstania Warszawskiego, ludzie z dawnych Kresów, ale z Kaszub i Pomorza?23

Słowa Fikusa potwierdzają opinię Dyrektora Muzeum Uniwersytetu Gdańskiego Jana Daniluka, który twierdzi, że pamięć o społecznościach odmiennych czy peryferyjnych jest słabo obecna w przestrzeni publicznej, została bowiem zmarginalizowana przez ogólnie dominującą narrację historyczną. Dodatkowo trzeba także uwzględnić siłę propagandy tak zwanej Polski ludowej, kiedy to oskarżano Kaszubów o separatyzm, niemieckość i kolaborację $\mathrm{z}$ hitlerowcami. Jednakże ani zmarginalizowanie tematu, ani propaganda nie zaprzeczą faktom, że tysiące Pomorzan i Kaszubów było represjonowanych po wkroczeniu Armii Czerwonej w 1945 roku.

21 E. Pryczkowski, op. cit., s. 12.

22 Cyt. za: ibidem, s. 29-30.

23 Ibidem, s. 31-32.

Wrocławskie Studia Wschodnie 24, 2020

(C) for this edition by CNS 


\section{„Gdy w Gdyni była...”}

W niniejszym artykule swoją uwagę skupiam wyłącznie na casusie Gdyni - mieście owianym mitem, mieście sukcesu, z którego ludność została wypędzona „fizycznie, moralnie i duchowo" 24 , mieście naznaczonym silnie propagandą zarówno polityki II Rzeczypospolitej, jak i tak zwanej Polski ludowej, wreszcie mieście, które zostało zajęte przez Armię Czerwoną 28 marca 1945 roku.

Tutaj był ugór, pusty brzeg, na którym rosły liche zboża, skubały trawę stadka kóz i dął, zawodził wiatr od morza.

Teraz jest Gdynia, wielki port ramiona swe rozkłada, by wpływał w nie, wypływał z nich okrętów huf nie lada.

Do wszystkich krajów, świata stron wiodą je morskie drogi.

To o nich teraz śpiewa wiatr w fal pianie jak we zbożu.

Wróciła Polska na swój brzeg, $\mathrm{Ku}$ wiecznie swemu morzu. Szumi jej wiatr, od morza wiatr w fal pianie jak we zbożu.

O mury Gdyni skrzydła swe ociera on radośnie.

I wróży Polsce słony wiatr

Potęgę, co wciąż rośnie.

Tak Gdynię przedstawiała w propagandowym wierszu Powrót Ewa Szelburg-Zarembina, poetka, której utwory miały na celu przyniesienie „pożytku publicznego" 25 i których młodzież uczyła się w szkołach w okresie w okresie tak zwanej Polski ludowej.

Propagandowy wiersz Zarembiny wychwalający Gdynię zadziwia. Oczywiście nie swoją formą, lecz przekazem, jak pisze bowiem Małgorzata Sokołowska:

Powojenną Gdynię władza ludowa usiłowała sprowadzić do roli jednej z dzielnic Gdańska. Miała być zapleczem sypialnianym dla mas pracujących, pozbawionym znaczenia kulturalnego

24 F. Troszczyłów, op. cit., s. 16.

25 Zob. Była gwiazda PRL i pisarka, która wiele straciła - o Ewie Szelburg-Zarembinie opowiada Anna Marchewka, https://www.polskieradio.pl/8/378/Artykul/1255482,Ewa-Szel burgZarembina-poetka-odklejona-od-rzeczywistosci (dostęp: 15.12.2019). 
i gospodarczego. [...] celowym działaniem należy tłumaczyć systematyczne wyprowadzanie z Gdyni lub wyniszczenie wielu przedsiębiorstw. Stosunek władzy ludowej do Gdyni był schizofreniczny. Jednym tchem mówiono bowiem o niej, że taka piękna powstała wyłącznie dzięki zaangażowaniu świata pracy, jest pomnikiem trudu robotniczego, a równocześnie — że jest sanacyjnym bękartem i była siedliskiem wyzyskiwaczy, a nie żadnym sukcesem II RP26.

Cytowaną opinię należy także zestawić z meldunkami Delegatury Rządu RP na Kraj, zbieranymi od marca do czerwca 1945 roku. Urzędnicy przyjeżdżali do Gdyni i rejestrowali akty terroru sowieckiego i polskiego aparatu bezpieczeństwa w stosunku do ludności polskiej. Odnotowywano także przypadki rabunków dokonywanych przez żołnierzy sowieckich i dewastacji polskiego mienia ${ }^{27}$. W kontekście owych faktów historycznych siła propagandy zadziwia. Jednakże owo rozpowszechnianie obrazu Gdyni jako miejsca sukcesu towarzyszy rozwojowi miasta od samego początku jego przekształcania z wiejskiej osady we „wzniosły wysiłek narodu”28, zapoczątkowany w okresie II Rzeczypospolitej.

Gdynia uzyskała prawa miejskie 10 lutego 1926 roku, by w kolejnych latach powiększać swoje terytorium o otaczające ją wsie, między innymi Chylonię (1930), Witomino (1933) czy Cisową (1935). W okresie dwudziestolecia międzywojennego postrzegana była jako miasto, które między 1923 a 1939 rokiem, zbudowane zupełnie od podstaw, stało się „miastem marzeniem o prawdziwym polskim porcie" 29 . Nie dziwi więc euforia dziennikarzy, którzy thumnie przybywali do Gdyni w celu pisania reportaży i artykułów o budowie portu, rozwoju miasta, a także gdyńskiej architekturze i sztuce. Towarzyszący Gdyni od samego początku „mit sukcesu”, jak trafnie zatytułował swój artykuł Michał Graban ${ }^{30}$, był nie tylko spoiwem tożsamości mieszkańców miasta, lecz także Polaków w odradzającym się kraju.

Pisano też artykuły mniej wychwalające Gdynię. Oczywiście należą one do znacznej mniejszości, ale rzetelni dziennikarze, jak na przykład Zbigniew Uniłowski, doceniając urbanizację, starali się przekazać opinii publicznej nieco mniej optymistyczne „obrazki z miasta”. W artykule zamieszczonym w 14 numerze „Wiadomości Literackich” z 1937 roku, zatytułowanym Gdynia na co dzień, dziennikarz pisze:

26 M. Sokołowska, Przenoszenie ważniejszych instytucji z Gdyni do Gdańska, [w:] Korzenie Gdyni, cz. 3. Miasto pod specjalnym nadzorem. Materiaty z konferencji historycznej 30 stycznia 2004 r., Gdynia 2004, s. 52-53.

27 B. Chrzanowski, Gdynia w pracach Delegatury Rzadu RP na Kraj, [w:] Wysiedlenia Polaków z Gdyni w latach 1939-1945 przez okupanta niemieckiego. Materiały z VI sesji popularnonaukowej w dniu 24.04.2012 r., Gdynia 2012, s. 123.

28 Z. Uniłowski, Gdynia na co dzień, „Wiadomości Literackie” 1937, nr 27 (713).

29 I. Jopkieiwcz, Gdynia dwudziestolecia międzywojennego dziennikarskim okiem widziana, [w:] Wędrówki po dziejach Gdyni, red. D. Płaza-Opacka, T. Stegner, Gdynia 2004, s. 147.

30 Zob. M. Graban, Mit sukcesu — jako spoiwo tożsamości Gdyni, „Zeszyty Gdyńskie” 2016, nr 11, s. 29-38.

Wrocławskie Studia Wschodnie 24, 2020

(C) for this edition by CNS 
Pragnę powiedzieć obywatelom słodko drzemiącym w optymizmie, że sens Gdyni jest istotnie wielki, ale że nie wszystko jest w porządku, że trzeba wstrzymać rozśpiewany pochód i w skupieniu połatać wnętrze. Obawiam się, że pochód nieco się rozprasza, żeście się wyśpiewali i chcecie teraz Gdynię zostawić samą sobie ${ }^{31}$.

„Pochód" — podążając za Uniłowskim — chyba się jednak nie rozpraszał. Od momentu uzyskania praw miejskich do Gdyni napływali obywatele z całego kraju, planując osiedlić się tam na stałe. Rocznie przybywało od 4,5 do 6 tysięcy osób, a w 1937 roku ,zjechało do Gdyni 100000 ludzi pracy"32. Jak pisze Anna Orchowska-Smolińska: „Wzrost demograficzny nie wyhamował nawet, gdy rynek pracy się nasycił i wyczerpywały możliwości zapewnienia stałego zatrudnienia wszystkim przybywającym"33. Do miasta przyjeżdżali przedsiębiorcy, młodzi i wykształceni specjaliści, artyści, bezrobotni, letnicy, a także pasażerowie słynnych polskich transatlantyków. Miasto i port tętniły życiem.

Dziwi więc fakt, że tak prężnie rozwijające się polskie miasto nie zostało bardziej zniszczone podczas II wojny światowej. Jak pisze Dariusz Kardas:

W samej zabudowie zaszły niewielkiego typu zmiany. Jedynym dorobkiem niemieckim na terenie miasta, w ciągu 5 lat, było wzniesienie niewielkiego zespołu domów mieszkalnych na wzgórzu Foscha, wzdłuż ul. Morskiej i w Chyloni oraz wybudowanie karykaturalnego budynku, który rychło uzyskał zgodnie z wyglądem nazwę „Stodoły”. Działania wojenne w 1945 r. zniszczyły Gdynię w ok. 20\%. Legło w gruzach lub zostało silnie uszkodzonych 1413, tj. 16,4\% budynków, a częściowo zrujnowanych 3892, tj, 45\%. Zniszczeniu uległo ok. 40\% sieci komunikacyjnej, wysadzono w powietrze 1 wiadukt i spalono budynki dworcowe. Gorszy widok przedstawiał port. Oddziały niemieckie dokonały w porcie ogromnych zniszczen ${ }^{34}$.

Pomorskie porty odgrywały w ostatnich latach wojny znaczącą rolę wojskową, a także transportową, port gdyński zaś stał się głównym centrum remontowo-szkoleniowym i zaopatrzeniowym niemieckiej Marynarki Wojennej (Kriegsmarine). Stocznie w Gdyni i w Gdańsku masowo produkowały okręty podwodne, stąd Armia Czerwona skoncentrowała swoje działania na opanowaniu przede wszystkim portów leżących w Zatoce Gdańskiej, a sama Gdynia (Port Gotów - Gotenhafen), stała się, jak słusznie zauważa Małgorzata Agnieszka Stepko, drugoplanowym terenem walk w stosunku do Gdańska ${ }^{35}$.

31 Z. Uniłowski, op. cit.

32 A. Orchowska-Smolińska, Problemy mieszkaniowe w budującej się Gdyni, ,,mieście poszukiwaczy złota”, „Studia KPZK” 2017, nr 180, s. 273.

33 Ibidem.

34 D. Kardas, Gdynia w pracach Delegatury Rządu dla Spraw Wybrzeża w Gdańsku w latach 1945-1947, [w:] Korzenie Gdyni, cz. 2. Gdynia w czasach stalinowskich. Materiaty z konferencji historycznej 6 marca 2003 r., Gdynia 2003, s. 33.

35 M.A. Stepko, Z dziejów Gdyni w okresie II wojny światowej. Praca magisterska napisana pod kierunkiem prof. dr. hab. Marka Andrzejewskiego, Gdańsk 2005, s. 127, http://2wojna. gdynia.pl/wp-content/uploads/2017/12/10_stepko.pdf (dostęp: 15.12.2019).

Wrocławskie Studia Wschodnie 24, 2020

(C) for this edition by CNS 
Do Gdyni „po wyzwoleniu” zaczęli przybywać wysiedleni przez Niemców dawni mieszkańcy miasta, by „dziełem wspólnego wysiłku” zbudować „Nową Gdynię" 36 . Jednak nie wszyscy oni mogli uczestniczyć w czynie społecznym.

\section{Deportacje gdynian na Sybir w świetle protokołów przesłuchań świadków Instytutu Pamięci Narodowej}

Zajmując się kwestią deportacji ludności z Pomorza Gdańskiego w głąb ZSRS po wkroczeniu na te tereny Armii Czerwonej w 1945 roku, nie sposób nie odwołać się do dokumentów pochodzących ze śledztw prowadzonych przez gdański oddział Instytutu Pamięci Narodowej, który ma w swoich archiwach 70 tomów akt dotyczących casusu deportacji ludności z Pomorza. Pośród dokumentów, znajdują się archiwalia dotyczące wielu pomorskich miejscowości, wśród nich między innymi: Gdańska, Gdyni, Kartuz, Rumii, Sopotu, Starogardu Gdańskiego czy Tczewa.

W niniejszym artykule, ze względu na analizowane zagadnienie, powołam się na wybrane dokumenty dotyczące deportacji ludności z Gdyni, zwracając przy tym uwagę, że podczas kwerendy nie znalazłam ich wiele ${ }^{37}$. Zeznania ówczesnych obywateli Gdyni nikną w liczbie protokołów mieszkańców sąsiednich pomorskich miejscowości lub osób, które wyemigrowały do Gdyni, a sowieckich represji doświadczyły w miejscach wcześniejszego zamieszkania. Wśród archiwaliów, którymi się posługuję, znajdują się przede wszystkim protokoły przesłuchań świadków, będące wypowiedziami (osobistymi wyznaniami i komentarzami) osób doświadczonych sowieckimi represjami. Umożliwiają one lepsze (choć ciągle niepełne i wymagające dalszych analiz) rozpoznanie w obszarze uwarunkowań psychospołecznych indywidualnych przeżyć deportacji gdynian oraz swoistości ich doświadczenia, także wspólnotowego.

W dniu 22 kwietnia 2009 roku przesłuchiwana przez Lesława Ordona — prokuratora Oddziałowej Komisji Ścigania Zbrodni przeciwko Narodowi Polskiemu w Gdańsku — Inga Fluder, urodzona w 1943 roku w Gdyni, zeznała, że jej rodzice Władysław i Gertruda Fiałek byli Polakami i mieszkali w Gdyni. Jej ojciec pracował w stoczni i został wywieziony przez Niemców na przymusowe roboty do Rzeszy. Wracając w 1945 roku do Polski, został zatrzymany przez żołnierzy Armii Czerwonej i natychmiast wywieziony

36 Ibidem, s. 134.

37 Kwerendę w gdańskim oddziale Instytutu Pamięci Narodowej odbyłam w grudniu 2018 roku wraz z kierownikiem Działu Naukowego Muzeum Pamięci Sybiru — dr. Marcinem Zwolskim. Przeanalizowaliśmy ponad 200 tomów akt (70 dotyczących deportacji ludności z Pomorza Gdańskiego i 120 dotyczących Wileńszczyzny). Dziękuję prokuratorowi Tomaszowi Jankowskiemu za możliwość przeprowadzenia kwerendy.

Wrocławskie Studia Wschodnie 24, 2020

(C) for this edition by CNS 
w głąb ZSRS w okolice Uralu, gdzie pracował na roli. Nigdy nie podpisał NLN. Do Gdyni powrócił po wojnie, gdzie pracował w porcie. Zmarł w 1980 roku. Jak zeznaje córka: „Był silnym człowiekiem i może to pomogło mu przeżyć w obozie" ${ }^{\prime 3}$.

Z kolei 16 grudnia 2009 roku przesłuchiwany przez prokuratora Ordona Gotfryd Pułakowski, urodzony w 1937 roku w Gdyni, zeznał, że jego ojciec Bogusław Pułakowski urodził się w 1900 roku na terenie Rzeszy Niemieckiej, a matka Rozalia przyjechała do Gdyni ze wsi Frąca, do pracy w porcie, gdzie poznała swojego przyszłego męża. Bogusław i Rozalia zawarli związek małżeński w 1936 roku jako obywatele państwa polskiego. W 1939 roku cała rodzina Pułakowskich doświadczyła represji niemieckich, wskutek których zostali zmuszeni do opuszczenia mieszkania w Gdyni. Ukrywając się, uniknęli wywiezienia z miasta. Ojciec Gotfryda był poszukiwany przez Niemców, należał bowiem do ,jakiejś polskiej organizacji”. W trakcie wojny nie mieszkał z rodziną i jak zeznaje syn, przebywał w ,pomocniczych oddziałach niemieckich", mieszkając w barakach przy dawnej ulicy Migały w Gdyni. Po alianckich nalotach bombowych na Gdynię, przeprowadzonych w latach 1944-1945, Bogusław Pułakowski służył na terenie miasta w oddziałach ratunkowych jako sanitariusz. Gotfryd Pułakowski jest pewien, że ojciec w Wehrmachcie nie służył, ale uważa, iż fakt, że Niemcy traktowali ojca ,jak Niemca", wynikał z tego, że urodził się na terytorium Rzeszy. Od momentu wkroczenia Armii Czerwonej do Gdyni (od strony Chyloni i Witomina) Bogusław Pułakowski uznany został za zaginionego. Z relacji syna wynika, że o losie ojca rodzina dowiedziała się od nieznajomego mężczyzny dopiero po wojnie. Bogusław Pułakowski miał zostać drogą morską wywieziony do obozu w Pietrozawodsku przy granicy z Finlandią. Tam też zachorował ponoć na tyfus i zmarł. Nieznajomy mężczyzna miał osobiście pochować Pułakowskiego, a wdowie oddać prywatne rzeczy męża — w tym jego rodzinne zdjęcie. Bogusław Pułakowski został uznany za zmarłego na podstawie wniosku żony i zeznań świadka. Syn Gotfryd swoje zeznanie konkluduje słowami:

Nie potrafię określić tego, czy ojciec mój posiadał w czasie wojny niemieckie obywatelstwo. Nie mogę wykluczyć, że ojciec mój był zmuszony do przyjęcia jakiejś formy niemieckiego obywatelstwa, ale jaką grupę narodowościową przyjął — tego nie wiem ${ }^{39}$.

Przed tym samym prokuratorem 31 grudnia 2009 roku zeznawała Zofia Maria Młyńska, urodzona w 1938 roku w Gdyni. Jej rodzice Edmund i Elżbieta

38 Protokół przesłuchania świadka Ingi Fluder z dnia 22 kwietnia 2009 roku, sygn. akt S 15/00/Zk.

39 Protokół przesłuchania świadka Gotfryda Pułakowskiego z dnia 16 grudnia 2009 roku, sygn. akt S 15/00/Zk. 
Hebel po ślubie osiedli w Gdyni. Matka zajmowała się domem, ojciec zaś pracował początkowo jako robotnik, a w czasie okupacji niemieckiej jako stoczniowiec. Po wkroczeniu Armii Czerwonej do Gdyni cała rodzina uciekła do mieszkających w miejscowości Kielno kuzynów. Po wojnie powrócili do Gdyni. Ojciec, jak wspomina świadek, udał się w stronę stoczni i portu w celu obejrzenia wojennych zniszczeń. Został zatrzymany przez żołnierzy Armii Czerwonej na przystanku Gdynia-Stocznia, gdzie patrolowano przechodzących tamtędy mężczyzn. Wszyscy zatrzymani musieli w kolejnych dniach przymusowo pracować przy odgruzowywaniu miasta. Ojciec Zofii został następnie wywieziony do Gdańska i tam, przebywając w obozie GdańskMaćkowy (obozie dla sprawdzanych i zatrzymanych przez NKWD), zmarł. Jakie miały być jego dalsze powojenne losy? Jak wspomina córka: „Nie walczył przeciwko Armii Czerwonej. $Z$ jakich przyczyn został zatrzymany, tego nie potrafię powiedzieć" 40 .

Choć Wielki Kack oficjalnie jest dzielnicą Gdyni dopiero od 1953 roku, na uwagę zasługują dwa zeznania, które chciałabym w niniejszym artykule przytoczyć. Są one, jak sądzę, dopełnieniem obrazu tragicznych wydarzeń w Gdyni po 1945 roku. Dnia 30 grudnia 2009 roku przesłuchiwani byli przez prokuratora Ordona Władysław Kaszubowski, urodzony w 1937 roku w Wielkim Kacku, oraz Zygmunt Rietz, urodzony tamże w 1939 roku.

Pierwszy ze świadków zeznał, że jego ojciec Józef Kaszubowski (urodzony w roku 1899) mieszkał w Wielkim Kacku wraz z żoną Gertrudą i dziećmi. Ojciec świadka pracował w Gdyni, w firmach budowlanych. Z obawy przed zbliżającym się frontem sowieckim wraz z rodziną próbował uciec z Wielkiego Kacka. Został zatrzymany nieopodal miejscowości Chwaszczyno i wówczas Władysław widział ojca po raz ostatni. Świadek poznał jego historię z opowieści matki, która przybliżyła mu rodzinne losy. Ponoć nieznajomy mężczyzna przekazał Gertrudzie, że Józef trafił do ZSRS, gdzie zmarł. Potwierdzeniem tego faktu jest przedstawiony prokuratorowi Ordonowi odpis skróconego aktu zejścia, wydanego w 1948 roku w Urzędzie Stanu Cywilnego w Gdyni. Józef Kaszubski zmarł 31 grudnia 1945 roku w Smoleńsku ${ }^{41}$.

Drugi świadek - Zygmunt Rietz — oświadczył, że jego polscy rodzice Franciszek (urodzony w 1908 roku) i Maria mieszkali w Wielkim Kacku. Ojciec pracował jako piekarz, a matka zajmowała się domem. W 1939 roku po mobilizacji do polskiego wojska mężczyzna został wcielony do artylerii i walczył przeciwko Niemcom na Helu. Ojca widział po raz ostatni, gdy wraz z matką odwiedzili go w miejscowości Kielno, gdzie przebywał pod

40 Protokół przesłuchania świadka Zofii Marii Młyńskiej z dnia 31 grudnia 2009 roku, sygn. akt S 15/00/Zk.

41 Protokół przesłuchania świadka Władysława Kaszubowskiego z dnia 30 grudnia 2019 roku, sygn. akt S 15/00/Zk. 
nadzorem żołnierzy wojska sowieckiego. Z opowiadań matki, która posiadła informacje od nieznajomego mężczyzny, Rietz dowiedział się, że jego ojciec przebywał w obozie na Uralu, tam też zmarł i został pochowany. Świadek kończy swoje zeznanie słowami:

Nie przypuszczam, by ojciec mój po 1939 roku służyć miał w Wehrmachcie. Nie sądzę, by ojciec mój miał walczyć przeciwko wojsku radzieckiemu. W jakich okolicznościach i z jakich przyczyn ojciec mój znalazł się zatrzymany w Kielnie — tego nie wiem ${ }^{42}$.

Zeznania świadków dotyczące deportacji mieszkańców Gdyni są fragmentaryczne i niepełne. Po zapoznaniu się z dokumentacją powstaje wiele pytań, a akta śledztwa wymagają dalszej, pogłębionej analizy i naukowej refleksji. Z badanego materiału wynika, że temat deportacji gdynian pozostaje nadal „białą plamą” na kartach współczesnej polskiej historii, a wydaje się być składnikiem niezbędnym, aby w pełni zrozumieć zawiłe losy Pomorza Gdańskiego po 1945 roku. Zaryzykuję pytanie: czy nadal, mimo upływu ponad 30 lat od upadku tak zwanej Polski ludowej, nie jesteśmy w stanie owych luk wypełnić? A może nadal brakuje nam odwagi w dyskusji na temat tak zwanych spraw trudnych i w związku z tym pewnych kwestii wolimy nie poruszać w ogólnoakademickim dyskursie?

\section{Refleksje}

Decyzja o wyborze sformułowanego w tytule tematu i casusu Gdyni jako materiału badawczego nie jest przypadkowa. Gdynia uzyskała prawa miejskie 10 lutego 1926 roku, a w tym samym dniu 14 lat później Sowieci przeprowadzili tak zwaną pierwszą, masową deportację ludności polskiej na Sybir. W Gdyni data 10 lutego to święto mające wydźwięk pozytywny (taką nazwę nosi też jedna z najstarszych gdyńskich ulic), na wschodnich zaś terenach kraju to dzień refleksji. Warto także zaznaczyć, że wielu Kresowiaków po aneksji dawnego wschodniego pogranicza II Rzeczypospolitej przez Armię Czerwoną zostało przesiedlonych lub emigrowało dobrowolnie na Pomorze Gdańskie, w tym właśnie do Gdyni. Koincydencja ta jest interesująca, tym bardziej że wspomnień gdynian o deportacji w głąb ZSRS po wkroczeniu Armii Czerwonej na te tereny w 1945 roku jest niewiele. A przecież mieszkańców deportowano, o czym świadczą nie tylko przywołane dokumenty przechowywane w gdańskim oddziale Instytutu Pamięci Narodowej, ale także aktywnie działające Koło Sybiraków i jakże wymowny pomnik poświęcony Zesłańcom Sybiru przy ulicy Armii Krajowej, znajdujący się naprzeciw Teatru Muzycznego. Został on zbudowany z inicjatywy gdyńskie-

42 Protokół przesłuchania świadka Zygmunta Rietza z dnia 30 grudnia 2019 roku, sygn. akt S 15/00/Zk.

Wrocławskie Studia Wschodnie 24, 2020

(C) for this edition by CNS 
go Koła, a jego odsłonięcie nastąpiło w 65. rocznicę ataku ZSRS na Polskę - 17 września 2004 roku (autorami pomnika są Maria Jasińska, Mirosław Łaszek i Emilia Kaus). Może więc warto dogłębniej zająć się zagadnieniem deportacji ludności Gdyni po 1945 roku, tym bardziej że „świadkowie historii" odchodzą, a zgromadzone dotychczas materiały nie są liczne ${ }^{43}$.

A przecież: „Krwią pisana historia Gdyni dowiodła, że nie tylko potrafiliśmy umiejętnie gospodarować na naszym skrawku Bałtyku, ale również bronić go z całym poświęceniem" 44 .

\section{Bibliografia}

Baziur G., Armia Czerwona na Pomorzu Gdańskim 1945-1947, Warszawa 2003.

Bykowska S., Karać czy rehabilitować? Powojenne ustawodawstwo polskie wobec osób wpisanych na Niemiecka Listę Narodowościowa, „Czasopismo Prawno-Historyczne” 64, 2012, nr 1 .

Bykowska S., Rehabilitacja i weryfikacja narodowościowa ludności polskiej w województwie gdańskim po II wojnie światowej, Gdańsk 2012.

Chodubski A., O mitycznym postrzeganiu tożsamości Gdyni, „Zeszyty Gdyńskie” 2016, nr 11.

Chrzanowski B., Gdynia w pracach Delegatury Rządu RP na Kraj, [w:] Wysiedlenia Polaków z Gdyni w latach 1939-1945 przez okupanta niemieckiego. Materiaty z VI sesji popularnonaukowej w dniu 24.04.2012 r., Gdynia 2012.

Chrzanowski B., Gąsiorowski A., Steyer K., Polska podziemna na Pomorzu w latach 1939 1945, Warszawa 2005.

Drozd J., Gdynianie. Lista (niepetna) strat osobowych Gdyni w II Wojnie Światowej 19391945, cz. 1. Ludność cywilna, Gdynia 2003.

Gliniecki T., Panto D., Krzywy obraz wojny. Armia Czerwona w Gdańsku i Prusach w 1945 r., Gdańsk 2019.

Golon M., Deportacje Polaków z Pomorza do obozów NKWD w ZSRR w 1945 r., [w:] Przez Sybir na ziemię gdańska, cz. 2, red. C. Riedl, Gdańsk 2009.

Golon M., „Pomorska obława”. Deportacje Polaków z Pomorza do obozów NKWD w ZSRR w 1945 roku, [w:] Polska 1939-1945: straty osobowe i ofiary represji pod dwiema okupacjami, red. W. Materski, T. Szarota, Warszawa 2009.

Golon M., Represje Armii Czerwonej i NKWD wobec polskiej konspiracji niepodległościowej w latach 1944-1956: część I, „Czasy Nowożytne” 1996, nr 1.

Graban M., Mit sukcesu - jako spoiwo tożsamości Gdyni, „Zeszyty Gdyńskie” 2016, nr 11.

Kardas D., Gdynia w pracach Delegatury Rzadu dla Spraw Wybrzeża w Gdańsku w latach 1945-1947, [w:] Korzenie Gdyni, cz. 2. Gdynia w czasach stalinowskich. Materiaty z konferencji historycznej 6 marca 2003 r., Gdynia 2003.

Jastrzębski W., W dalekim, obcym kraju: deportacje Polaków z Pomorza do ZSRR w 1945 roku, Bydgoszcz 1990.

43 Dziękuję kierowniczce Biblioteki Muzeum II Wojny Światowej w Gdańsku — Patrycji Śliwińskiej i kustoszowi Markowi Zambrzyckiemu za pomoc w kwerendzie oraz kierownikowi

Działu Historycznego Muzeum Miasta Gdyni dr. Marcinowi Szerle za cenne wskazówki.

44 Trzy Gdynie... 
Jopkiewicz I., Gdynia dwudziestolecia międzywojennego dziennikarskim okiem widziana, [w:] Wędrówki po dziejach Gdyni, red. D. Płaza-Opacka, T. Stegner, Gdynia 2004.

Kaszubi w PRL, red. M. Adamkowicz, I. Joć, Gdańsk 2007.

Kąkol B., Kartuzy - 1945 r., http://www.szwajcaria-kaszubska.pl/kaszuby/muzeum-kaszubskie/item/991-kartuzy-1945-r (dostęp: 1.12.2019).

Krogulski M.L., Okupacja w imię sojuszu. Armia Radziecka w Polsce 1956-1993, Radzymin 2019.

Kulesza W., Polacy wpisani na volkslistę a obowiazek stużby w Wehrmachcie w świetle wyroków Sądu Specjalnego w Toruniu, „Studia Iuridica Toruniensia” 23, 2018.

Niemiecka Lista Narodowościowa, https://www.gedanopedia.pl/gdansk/?title=NIEMIECKA_ LISTA_NARODOWO\%C5\%9ACIOWA (dostęp: 1.12.2019).

O sowieckich represjach wobec Polaków ze Stawomirem Kalbarczykiem, Tomaszem Łabuszewskim i Kazimierzem Krajewskim rozmawia Barbara Polak, „Biuletyn IPN” 2003, nr 11 (34).

Orchowska-Smolińska A., Problemy mieszkaniowe w budującej się Gdyni, , mieście poszukiwaczy złota”, „Studia KPZK” 2017, nr 180.

Projekt edukacyjny ,, Miasto Gdynia w okresie II Wojny Światowej”, t. 1, Gdynia 2019.

Pryczkowski E., Wspomnienia kaszubskich Sybiraków, Banino 2010.

Rodowici mieszkańcy Pomorza wstydza się podpisania volkslisty. ,, Terror zacząt się od pierwszych dni wojny", https://trojmiasto.wyborcza.pl/trojmiasto/1,35612,14845394,Rodowici_mieszkancy_Pomorza_wstydza_sie_podpisania.html?disableRedirects=true (dostęp: 14.12.2019).

Słomczyński T., Zapomniani Sprawiedliwi wśród Narodów Świata, czyli jak Kaszubi ratowali Żydów, „Plus Minus”, https://www.rp.pl/Plus-Minus/303159914-Zapomniani-Sprawiedliw i-wsrod-Narodow-Swiata-czyli-jak-Kaszubi-ratowali-Zydow.html (dostęp: 5.12.2019).

Sokołowska M., Przenoszenie ważniejszych instytucji z Gdyni do Gdańska, [w:] Korzenie Gdyni, cz. 3. Miasto pod specjalnym nadzorem. Materiaty z konferencji historycznej 30 stycznia 2004 r., Gdynia 2004.

Stepko M.A., Z dziejów Gdyni w okresie II wojny światowej, praca magisterska napisana pod kierunkiem prof. dr. hab. Marka Andrzejewskiego, Gdańsk 2005, http://2wojna.gdynia.pl/ wp-content/uploads/2017/12/10_stepko.pdf (dostęp: 15.12.2019).

Straty osobowe Gdyni w okresie II wojny światowej, oprac. R. Toczek, Gdynia 2018.

Troszczyłów F., Los wypędzonych Pomorzan 1939-1945, Gdynia 2010.

Trzy Gdynie, „Wiadomości Polskie polityczne i literackie. Tygodnik” 1941, nr 41 (83), http://2 wojna.gdynia.pl/wp-content/uploads/2017/12/14_trzy_gdynie.pdf (dostęp: 14.12.2019).

Uniłowski Z., Gdynia na co dzień, „Wiadomości Literackie” 1937, nr 27 (713).

Ustawa z 18 grudnia 1998 roku o Instytucie Pamięci Narodowej — Komisji Ścigania Zbrodni przeciwko Narodowi Polskiemu. Dz.U. z 1998 r. Nr 155, poz. 1016.

Wysiedlenia Polaków z Gdyni w latach 1939-1945 przez okupanta niemieckiego. Materiaty z VI sesji popularnonaukowej w dniu 24.04.2012 r., Gdynia 2012.

Zwolski M., Represje wobec ludności cywilnej po wkroczeniu Armii Czerwonej 1944-1945 [mps tekstu udostępniony przez autora].

\section{Audycje radiowe}

Była gwiazdą PRL i pisarka, która wiele straciła - o Ewie Szelburg-Zarembinie opowiada Anna Marchewka, https://www.polskieradio.pl/8/378/Artykul/1255482,Ewa-SzelburgZarembina-poetka-odklejona-od-rzeczywistosci (dostęp: 15.12.2019). 


\section{Archiwalia Oddziału Instytutu Pamięci Narodowej w Gdańsku}

Protokół przesłuchania świadka Ingi Fluder z dnia 22 kwietnia 2009 roku, sygn. akt S 15/00/Zk. Protokół przesłuchania świadka Władysława Kaszubowskiego z dnia 30 grudnia 2019 roku, sygn. akt S 15/00/Zk.

Protokół przesłuchania świadka Zofii Marii Młyńskiej z dnia 31 grudnia 2009 roku, sygn. akt S $15 / 00 / Z k$.

Protokół przesłuchania świadka Gotfryda Pułakowskiego z dnia 16 grudnia 2009 roku, sygn. akt S 15/00/Zk.

Protokół przesłuchania świadka Zygmunta Rietza z dnia 30 grudnia 2019 roku, sygn. akt S 15/00/Zk. 